\title{
Identifying Factors Influencing Visionary Leadership: An Empirical Evidence from Thai Manufacturing Industry
}

\author{
Walailak Atthirawong ${ }^{1 *}$, Kaseam Bunnoiko ${ }^{2}$, Wariya Panprung ${ }^{3}$ \\ ${ }^{1,2}$ King Mongkut's Institute of Technology Ladkrabang, Bangkok, Thailand \\ ${ }^{3}$ Phranakhon Rajabhat University, Bangkok, Thailand
}

\section{Keywords: \\ Leadership, Thai \\ Manufacturing Industry, \\ Supply Chain, Visionary \\ Leadership}

Received

26 November 2020

Received in revised form

06 December 2020

Accepted

10 December 2020

*Correspondence:

walailaknoi@gmail.com

\begin{abstract}
Supply chain consists of all integrated activities that bring products to markets in the right time, at the right place while creating value added in order to satisfy customers. The performance of all activities in the supply chain requires the cooperation and coordination of complex processes across all members in organizations. Successful supply chain management relies on great leaders, who can communicate with their supply chain members and encourage feedback systems to improve the workplace environment. The leaders have the principal goal of making use of modern, scientific, technical and innovative methods in the implementation of tasks and activities. Therefore, the aim of this study was to investigate key factors affecting visionary leadership in the context of Thai manufacturing industry. Data were collected using survey questionnaires administered to supply chain managers in each manufacturing company located in industrial estates across the country. A total of 500 valid questionnaires were received and analyzed using structural equation modeling. The results revealed that communication skill had the highest impact on visionary leadership, followed by organization climate and creativity. The study outcome could be to the benefit of managers, who strive to generate visionary leadership and realize how important it is to incorporate communication skills as one of the most powerful instruments to improve leadership.
\end{abstract}

The leadership concept first emerged in 1970 (Kuei, Madu, \& Lin, 2001; Van Hock, Chatham, \& Wilding, 2002), and is considered to be the heart of management of any organization. Many scholars, for example Jacobs (1970), and Boles and Davenport (1975) defined leadership as interpersonal relationships, when a person tries to persuade others to 
follow his action to achieve set goals. Later, during the years 1980-1989, scholars added even more sophisticated meanings for leadership as the process for developing interpersonal relationships and the manifestation of influence over others (Bryman, 1992). Leadership is the ability of a leader to create something new and supervise workers and subordinators to achieve their tasks at a highest level. In other words, change leaders must be able to motivate and inspire workers and colleagues in performing tasks, so their vision could be materialized and continued to inspire everyone to be involved in ownership. Furthermore, Podsakoff, MacKenzie, Moorman, and Fetter (1990), and Bass and Riggio (2006) listed the key points on behavior: 1) identifying and articulating a vision, for example leadership behavior, indicating new opportunities for the organization, coupled with developing clear concepts and inspiration for the follower to bond with future vision, at the same time as 2) providing an appropriate model of leader behavior to set an example for others to follow with high values and leadership code-of-conduct, and 3) fostering the acceptance of group goals, for example leader behaviors with definite goals that would build cooperation among group members to enhance joint task forces, aiming for set objectives. Moreover, Steer and Porter (1991), and White and Bedner (1999) stated that the component of leadership as related to clarity of vision, depending on the leader ability to communicate clearly to reveal the future direction. According to White and Bedner (1999), charismatic leadership contributed to leader influence over the followers, so strong that they developed trust and confidence from the leader's vision.

A visionary leader role will certainly help an organization to achieve its expectations. The concept of visionary leadership must be connected and in line with competent leadership, which leads scholars to give multiple explanations (Vlok, 2012). For example, the effective leaders must have the following traits: have vision, be farsighted, teach consistently and develop personnel, as well as building good relationships and setting good examples in performing tasks (Hancott, 2005). This concept is in line with the idea of Van Staden, Scheepers, and Rieger (2000) who stated that leader traits comprise vision, direction in performing tasks, accountability, as well as willingness to support or provide assistance, and being a developer, including realizing the value of understanding others.

The organizational management in both small and large organizations may succeed with competent, knowledgeable leaders and be able to reach organization goals. Competent leaders would make the right decisions and prevent failures, leading to efficient performance. Effective leaders often seek self-improvement, theoretical and practical knowledge, as well as experiences from successful people, in order to make their organizations developing sustainability and excellence (Hinterhuber \& Friendrich, 2002; Hinterhuber \& Popp, 2002). Consequently, leadership and management style can lead to organizational effectiveness directly or indirectly.

To be successful in the challenging of today's global economy which is facing a range of disruptive forces, organizations need to develop the capabilities to achieve a much higher level of customized response to the different needs of different customers. Supply chain management consists of all integrated activities that bring products to markets in the right time, at the right place while creating value added in order to satisfy customers. Cooper and Sawaf (1997) and Lummus and Vokurka (1999) noted that the supply chain does not only include the manufacturers and suppliers, but transporters, warehouses, retailers and customers 
as well. The performance of all activities in the supply chain requires the cooperation and coordination of complex processes across all members in organizations. As such, many techniques are required to achieve supply chain management goals, for instance, process integration, collaboration, aligning measurement (Bowersox, Closs, Cooper, \& Bowersox, 2013; Lambert, Stock, \& Ellram, 1998).

Successful supply chain management relies on great leaders, who can communicate with their supply chain members and encourage feedback systems to improve the workplace environment. Leaders should have the capability to execute their responsibilities, talents and knowledge to accomplish the organizational goals effectively. Therefore, it was our interest to investigate factors, which affect visionary leadership of supply chain managers, so as to develop a causal model and further verify the validity, at which the theoretical structure can be used with empirical data in Thailand. Hence focused research has not been investigated in foreign and domestic publications as yet.

\section{Theoretical Background and Hypotheses Development}

Prior studies viewed visionary leadership as an emergent leadership paradigm (e.g., Podsakoff et al., 1990), which enhanced corporate sustainability and sustainable performance. Several researches (Groves, 2005; Howell \& Frost, 1989; Manasse,1986; Podsakoff et al., 1990)indicated five factors including communication, creativity, organization climate, emotional intelligent and traits that were found to influence visionary leadership. These concepts were used to form the model and hypotheses of this research.

\section{Visionary Leadership (VISL)}

Visionary leadership (VISL) is a capability of a leader to form and transmit vision of the organization, by providing directions and setting priorities to move the organization forward and achieve new levels of success (Nanus, 1992; Sashkin, 1987). According to Finkelstein and Hambrick (1997), a leader with vision must be wise and know how to apply strategy in an organization, that would lead the company to growth and success (Robbins, 2003). As a result, firms need leaders, that can drive its vision to achieve and sustain a competitive advantage.

Visionary leadership displays the ability of a leader to share vision to link the organizational desire to the future goal, through empowering subordinates to participate in identifying vision, which leads to organizational transformations (Berson, Shamir, Avolio, \& Popper, 2001; Brown \& Anfara, 2003). Commonly, the visionary leadership has three distinctive attributes: 1 ) sharing visions is the step to develop visionary leadership, as desired by the organization for the years to come (Kakabades, Kakabadse, \& Lee-Devis, 2005; Westley \& Mintzverg, 1989; Zaccaro \& Banks, 2004), by linking concepts for subordinates to assess outcomes, as well as creating effective vision, that focus on changes for progress, 2) procedures for imagination require the visionary leader to link and communicate vision to subordinates (Kakabades et al., 2005; Westley \& Mintzverg, 1989), and the leader must be able to explain the cause and effect of changing the vision and allow subordinates to participate in the decision, primarily to reduce the resistance, as well as increase joint responsibility for the decisions, and 3) steps to identify sub-visions that require the leader's role in managing changes in the organization (Kakabades et al., 2005; Westley \& Mintzverg, 
1989; Zaccaro \& Banks, 2004), by empowerment to boost subordinate confidence and enhance own efficiency (Bass, 1997), as well as ensure the vision acceptance.

The concept of visionary leadership has determined the significance and need to develop leadership among the staff, especially executives. According to Hickman and Silva (1984), Bennis and Nanus (1985), Westley and Mintzverg (1989), and Kantabutra and Avery (2002) key components of visionary leadership are: 1) formulating (FORM) means to create the image you want for the future by collecting information, analyzing data from both within and outside the organization, 2) articulating (ARTI) means, the ability to make stakeholders understand the vision and be willing to accept and follow it, and 3) implementing (IMPL) means, the ability to turn the vision into actuality, by links and transforms of the vision into policy, goals and targets of the organization.

\section{Communication (COMU)}

Communication (COMU) is a primary leadership task (Greenberg \& Baron, 1995) defined as the conceptualization of communication to individuals or organizations to deliver information to individuals, groups or other organizations. Dessler (1998) added an additional meaning as the party's internal exchange of information and other meaningful items. Effective communication would motivate and enhance employee performance. This concept was closely similar to Bearden, Netemeyer, and Mobley (1998), who described the communication as sending information and other meaningful statements from one party to others, through the symbol and both sides acknowledging the action. It was stated that communication was crucial in delivering a message, through positive and open communication, throughout an organization. Hence, the visionary leader should possess communication skills, both speaking and writing, as well as transmitting his vision to others, making subordinates understand and accepting the vision (Greenberg, 1995).

According to Howell and Frost (1989), communication is an instrument to measure and influence visionary leadership, whereas Manasse (1986) labeled creative thinking and emotional intelligence as influential factors toward visionary leadership. Manning and Robertson (2002) found the organizational atmosphere and communication had a direct influence on visionary leadership as well. In other words, effective communication is a crucial function and a key characteristic of a good visionary leader. Leadership requires skills in effective communication, to connect with stakeholders, who are investors, organization staff, customers and suppliers. According to Lunenburg and Omstein (1991), Charoenngam and Jablin (1999), and Wannasri (2007), the components of communication are: 1) communication skill (SKIL), the ability or skill to send to and obtain information from others to achieve objectives, using speaking, listening, writing and gesture skills, 2) communication channel (CHAN), the different ways, that executives can use to achieve the purpose of communication, including speaking, writing or active expressions, 3) communication form (COFO), the nature of the communications related to executive functions to achieve understanding and better coordination. Based on these logical and factual evidences (Charoenngam \& Jablin, 1999; Lunenburg \& Omstein, 1991; Wannasri, 2007), the following hypothesis was formed:

H1: Communication directly affects visionary leadership. 


\section{Creativity (CREA)}

Creativity (CREA) is one of the unique human characteristics - depending on individuals. Guilford (1959) claimed that creativity is the mental capacity to engage in different thinking and extensive aspects including the approach to solve problems, which create innovations. This idea is consistent with Torance (1962), who stated that creativity occurred, when a person had encountered problems, leading to new action or products as a result of gathering knowledge and previous experiences to link with new experiences. This concept coincided with the concept of Wallach and Kagan (1965), that creative thinking is an individual capability to bridge one thought to another through recall, thus creating a chain reaction.

The components of creative thinking from a scholarly point of view may be summarized as (Hawi, 2012; Kuo, 2016): 1) originality (ORIG), the ability to think of something new by knowledge experience accumulated and extensive applied usage, that can be used to solve the problem properly, 2) fluency (FLUE), the ability to create ideas from multiple different options quickly, i.e. be versatile, 3) flexibility (FLEX), thinking for answers in several categories and multiple directions, i.e. to think outside the scope or do not follow existing rules. It is independent in thinking and leads to creative thinking, and 4) elaboration (ELAB), the ability to see the details that other peoples do not see. It also includes links to relate things significantly, following the ideas of Guilford (1959), Torance (1962), and Jellen and Urban (1986). Therefore, our second hypothesis is:

$\mathbf{H}_{2}$ : Creativity directly affects visionary leadership.

\section{Organization climate (CLIM)}

Organization climate (CLIM) is a specific attribute of an organization, resulting from relationships between executives and members of the organization (Hoy \& Miskel, 2005). The management of the organizational climate is mainly within the duty of the person in the leader position. A positive climate is an important concept, that will facilitate the success of any organization. According to Lunenburg and Ornstein (1991), organization climate is the organization's environment with facilities already established, e.g., buildings and location of the establishment. This concept is consistent with Owens (1995), who mentioned the organization climate, as the factors that caused an individual to act differently, influenced by the organization environment. Grigsby (1991) argued that organization climate is the environment in the organization, related to individual performance, that is the bond, group attachment, administrative support, work schedule, pressure from work, control and innovation. This was perceived by organization members, as well as being motivated by the management. Wannasri (2007) found direct correlations between the organization climate and the effective communication among organization executives. Executives must build motivation and a proper environment to fit their organizations. The effective communication could be achieved in many ways, depending on whether the organization favored an open or closed atmosphere.

Dubrin (1984), Kangpen (2008), and Alipour (2011) summarized the components of organization atmosphere: 1) structure (CONS), the formal system of task reporting relationships which controls, directs, and encourages subordinates to work together for completing organizational objectives, 2) rewards and punishment (REWA), the system 
determining compensations for employees, who work by achieving organizational goals. In contrast, it imposes a penalty on employees, who do not follow company rules, 3) warmth and support (WARM), the practice encouraging employees to act to generate an overall benefit to the organization and themselves, and 4) risk and risk taking (RISK) is managing events or any actions, which might face to uncertain situation and include responsibilities of the organization for those events. These arguments lead to these hypotheses:

H3: Organization climate directly affects creativity.

H4: Organization climate directly affects visionary leadership.

H5: Organization climate directly affects communication.

\section{Emotional Intelligence (EMO)}

Emotional intelligence (EMO) is defined as a personal ability to display emotion rationally, namely, emotional perception, emotional expression and emotional self-control (Meyer, Paunonen, Gellatly, Goffin, \& Jackson, 1989). It relates to emotional self-awareness to build one's own inspiration, capable of managing one's emotion and emotions resulting from other relationships (Bass \& Riggio, 2006). Having emotional intelligence is vital for successful leaders, as they can use emotions to drive the organization forward. Based on Mayer and Salovey (1997), emotional intelligence is one's ability to adapt to one's emotion through the assessment an emotional display in three stages: 1) assessing emotion accurately and displaying proper emotions, 2) adapting one's emotion, as well as others', to the situation, and 3) displaying emotional intelligence differently, depending on individual ability to take advantage of one's own emotion, in finding solutions to problems or adapting to the situation, which should become creative if he or she is in a good mood. Emotional intelligence enhances the best practice and thus yields the best results, leading to employee enthusiasm to perform (Williams, Mathews, \& MacLeod, 1994). Thus, emotional intelligence is a vital factor for people to learn and practice, so they could be encouraged and inspired to success.

Bar-On (1997), Weisinger (1998), and Goleman, Boyatzis, and McKee (2002) considered that the key components of emotional intelligence including: 1) emotional self-awareness (EMSA), the reorganization and understanding their feelings and thoughts, emotions and their needs which cause different moods, 2) emotional self-control (EMC), the ability to cope with inappropriate emotions, to accept them and to change flexibly, 3) self-motivation (SELF), the ability of self-improvement - to build individual morale in every condition, also to improve the point of view for creating ideas and constructive actions, and 4) interpersonal relation management (INPE), the management building relationships, with care and sharing feelings with others and building relationships with others. Therefore, the following hypotheses were formed:

H6: Emotional intelligence directly affects organization climate.

H7: Emotional intelligence directly affects communication.

H8: Emotional intelligence directly affects visionary leadership.

H9: Emotional intelligence directly affects creativity.

All hypotheses are summarized in Figure 1. 


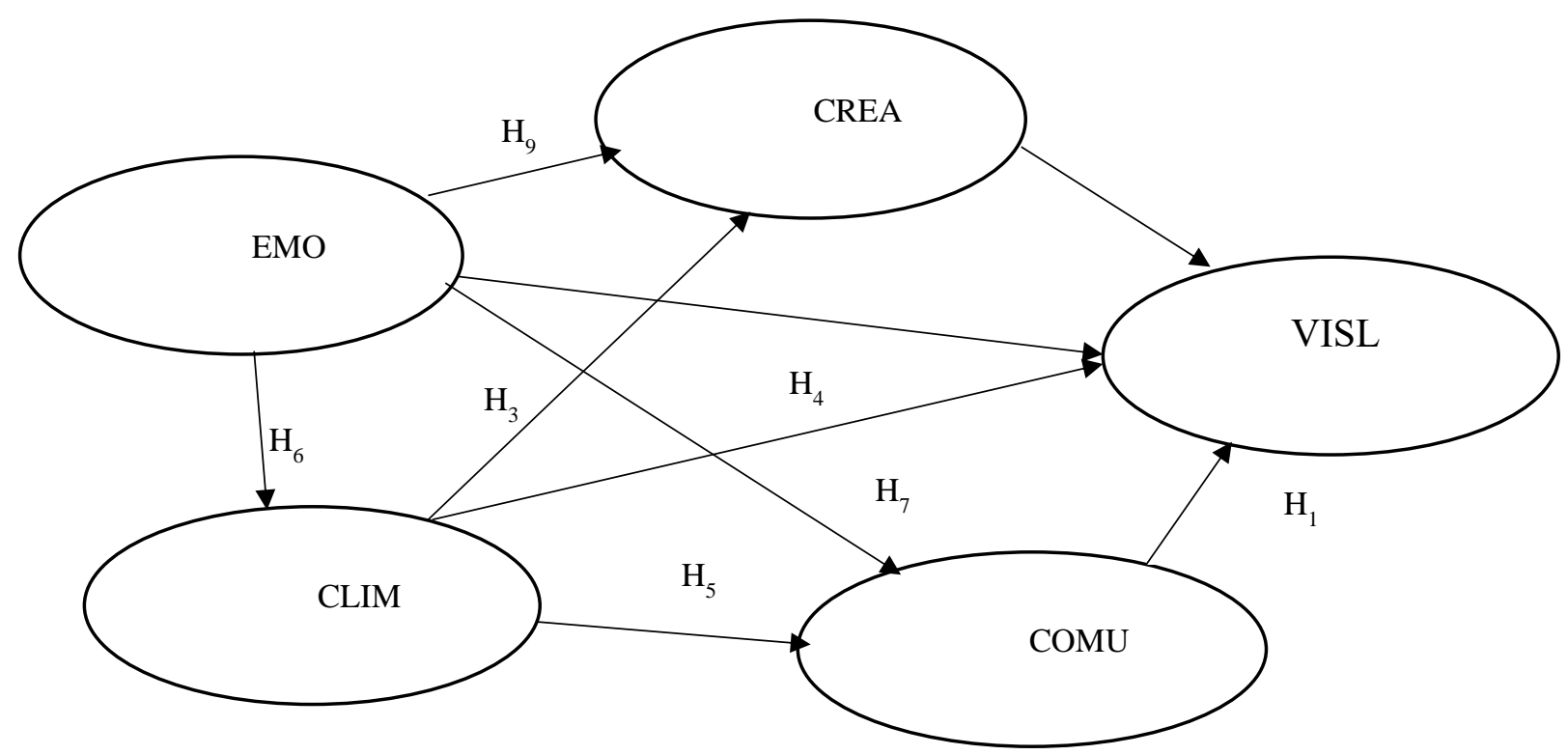

Figure 1. Conceptual model and Hypotheses of the study

\section{Research Objectives}

The objectives of this research are as follows:

i) To investigate the direct influence of communication, creativity, organization climate, emotional intelligent and traits towards visionary leadership of supply chain managers in Thai manufacturing industry.

ii) To develop a conceptual model to determine factors affecting visionary leadership of supply chain managers in Thai manufacturing industry using structural equation modeling (SEM).

\section{Method}

\section{Materials}

A questionnaire was developed, from literature review and previous studies with modifications, and used to collect data. A five level Likert scale evaluated responses, with 1 representing a 'strongly disagree', and 5 representing 'strongly agree'. The exogenous latent variable was visionary leadership (VISL). The endogenous latent variables were: 1) communication (COMU), 2) creativity (CREA), 3) organization climate (CLIM) and 4) emotional intelligent (EMO). Prior to questionnaire distribution, the quality of the questionnaire was tested for content validity and reliability (Hair, Black, Babin, Anderson, \& Tatham, 2006); it was examined by interviewing five key experts in the supply chain management, who experienced human development and leadership by identifying possible problems of formatting and/or comprehension of the questions, included in the questionnaire (Ravinelli \& Hambleton, 1997). Furthermore, a pilot study, using 30 responses, identified possible problems in terms of clarity and accuracy of the questionnaire. The reliability was .98 , which indicated that the questionnaire was appropriate and can be used for data collection (Creswell, 2002). 


\section{Data collection}

Population for this study was a set of supply chain managers in each manufacturing company located in industrial estates in Thailand, a total of 4,636 individuals (Department of Industrial Works, 2019). Based on sampling theory ratios from (Hair et al., 2006), a ratio of 20 individuals for each observed variable was considered reliable. Since our study had five latent variables with 23 observed variables, 460 questionnaires were targeted as sufficient and reliable. Data were collected by a simple random sampling technique. A total of 600 questionnaires were distributed and 500 complete questionnaires were returned and usable, representing $83 \%$ of all queries collected.

\section{Data analysis}

Data were analyzed using both descriptive statistics (i.e., frequency, percentage, minimum, maximum, mean, standard deviation, skewedness and kurtosis) and inferential statistics. Correlation coefficient was calculated to test the relationships between the variable models and AMOS was used to test our hypotheses.

\section{Results}

\section{Respondent profiles}

Table 1 displays the characteristics of the sample of 500 manufacturing supply chain managers, located in all regional industrial estates in Thailand. Most of the respondents $(59 \%)$ were males, $36-45$ years old $(48 \%)$, followed by a $46-55$ years old group $(27 \%)$. For educational level, 64\% had a bachelor's degree. For supply chain management experience, about half of the respondents (53\%) had 5-15 years experiences, followed by a group with $16-25$ years $(21 \%)$. The majority $(58 \%)$ had worked in large companies (>=200 employees), followed by $31 \%$, working in a medium-sized organizations (51-200 employees).

Table 1

Characteristics of Sample Group

\begin{tabular}{lcc}
\hline Characteristics & $\mathrm{n}$ & $\%$ \\
\hline Gender & & 58.8 \\
Male & 294 & 41.2 \\
Female & 206 & 20.8 \\
Age group & & 48.0 \\
36 years and below & 104 & 27.0 \\
$36-45$ years & 240 & 4.2 \\
$46-55$ years & 135 & 3.6 \\
56 years and above & 21 & 63.6 \\
Educational background & & 31.6 \\
Diploma & 18 & 1.2 \\
Bachelor degree & 318 & 19.4 \\
Master degree & 158 & 53.2 \\
Doctorate degree & 6 & 21.2 \\
Management experience in supply chain management & & 6.2 \\
Less than 5 years & 94 & 11.2 \\
$5-15$ years & 266 & 31.2 \\
$16-25$ years & 106 & 57.6 \\
26 years and above & 31 & \\
Organization size & & \\
Medium & 56 & 156 \\
Large & 288 & \\
\hline
\end{tabular}

Table 2 lists descriptive statistics components of the study variables. To test univariate normality, skewness and kurtosis values are between -2.00 and +2.00 which were acceptable 
values (Gravetter \& Wallnau, 2014). The casual relationship between the latent variables is meaningful if the correlation is strong. As shown in Table 3, it can be seen that the correlational relationship between visionary leadership and other latent variables are at least greater than .56 and have positive and statistically significance at.01 for all variable parings.

Table 2

Descriptive Statistics

\begin{tabular}{lcccccc}
\hline Variables & Min. & Max & $M$ & $S D$ & Skewness & Kurtosis \\
\hline Communication & 2.56 & 5.00 & 3.90 & 0.49 & -0.08 & -0.04 \\
Creativity & 2.29 & 5.00 & 3.83 & 0.52 & 0.02 & 0.05 \\
Emotional intelligence & 2.20 & 5.00 & 3.90 & 0.50 & -0.17 & 0.16 \\
Organization climate & 2.11 & 5.00 & 4.07 & 0.53 & -0.35 & 0.37 \\
Visionary leadership & $2 . .21$ & 5.00 & 3.80 & 0.51 & 0.03 & -0.14 \\
\hline
\end{tabular}

Table 3

Correlation Matrix

\begin{tabular}{|c|c|c|c|c|c|}
\hline Variables & COMU & CREA & EMO & CLIM & VISL \\
\hline COMU & 1.00 & & & & \\
\hline CREA & $.753 * *$ & 1.00 & & & \\
\hline EMO & $.650 * *$ & $.690^{* * *}$ & 1.00 & & \\
\hline CLIM & $.723^{* *}$ & $.702 * *$ & $.753^{* *}$ & 1.00 & \\
\hline VISL & $.736^{* *}$ & $.691^{* *}$ & $.566^{* *}$ & $.650 * *$ & 1.00 \\
\hline
\end{tabular}

\section{Structural Equation Model}

As evident in Figure 2, the values for the model fit indices in the structural model also showed that the model conformed well and indicated a good fit of the model, $\chi^{2} / d f=1.87$ and RMSEA $=.04$. The values of GFI $=.96, \mathrm{AGFI}=.93, \mathrm{CFI}=.98, \mathrm{IFI}=.98$ and NFI $=.97$ were consistent with the cutoff points and provided enough evidence for the model fit (Hair et al., 2006).

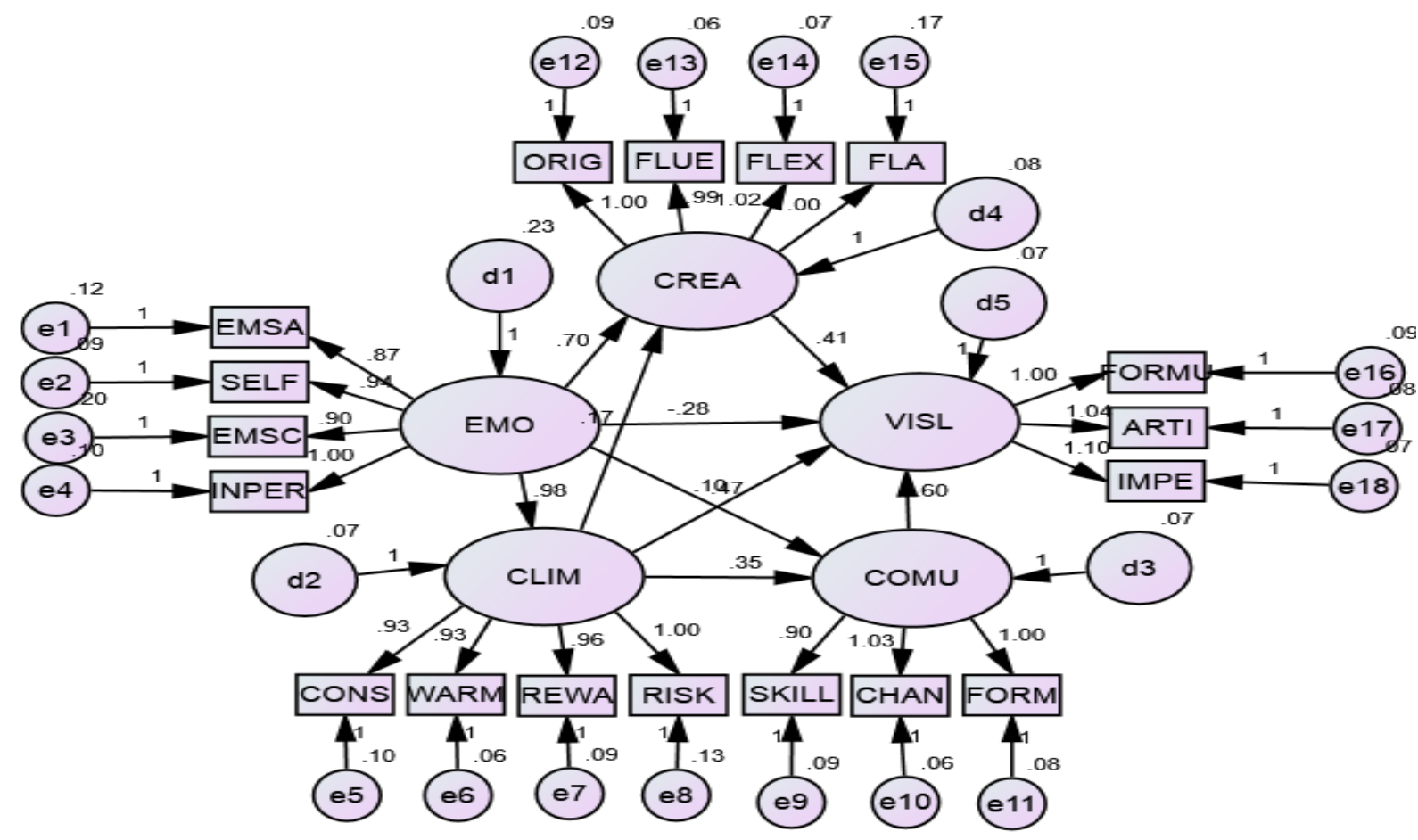

Figure 2. Structural model 
Out of the nine hypotheses, only one hypothesis $\left(\mathrm{H}_{4}\right)$ was not supported, i.e. organization climate had no direct impact on visionary leadership. Table 4 shows that $\mathrm{H}_{1}, \mathrm{H}_{2}$ and $\mathrm{H}_{8}$ were supported and thus communication, creativity and emotional intelligence were key components of visionary leadership for supply chain managers in the Thai manufacturing industry. $\mathrm{H}_{7}$ and $\mathrm{H}_{9}$ representing positive associations between emotional intelligence and communication, and creativity were supported as expected. Also, $\mathrm{H}_{6}$ and $\mathrm{H}_{5}$ were supported and significant to the organization climate and directly affected the communication climate and creativity. Similarly, organization climate was directly affected by creativity, supporting hypothesis, $\mathrm{H}_{3}$.

Table 4

Hypothesis and Goodness of Fit of Model Outcome

\begin{tabular}{lllllllll}
\hline Hypotheses & \multicolumn{2}{c}{ Variable path } & $\beta$ & $S E$ & $C R$ & $p$ & \multicolumn{2}{c}{ Supported } \\
\hline $\mathrm{H}_{1}$ & COMU & $\rightarrow$ & VISL & .60 & .07 & 8.32 & .00 & \multicolumn{2}{c}{ Yes } \\
$\mathrm{H}_{2}$ & CREA & $\rightarrow$ & VISL & .41 & .06 & 6.08 & .00 & Yes \\
$\mathrm{H}_{3}$ & CLIM & $\rightarrow$ & CREA & .17 & .07 & 2.11 & .03 & Yes \\
$\mathrm{H}_{4}$ & CLIM & $\rightarrow$ & VISL & .47 & .07 & 1.45 & .14 & No \\
$\mathrm{H}_{5}$ & CLIM & $\rightarrow$ & COMU & .35 & .07 & 4.89 & .00 & Yes \\
$\mathrm{H}_{6}$ & EMO & $\rightarrow$ & CLIM & .98 & .05 & 18.44 & .00 & Yes \\
$\mathrm{H}_{7}$ & EMO & $\rightarrow$ & COMU & .10 & .08 & 5.75 & .00 & Yes \\
$\mathrm{H}_{8}$ & EMO & $\rightarrow$ & VISL & -.28 & .11 & -2.43 & .01 & Yes \\
$\mathrm{H}_{9}$ & EMO & $\rightarrow$ & CREA & .70 & .09 & 7.26 & .00 & Yes \\
\hline
\end{tabular}

\section{Discussion and Conclusion}

We assessed the structural relationship among communication, creativity, organization climate, emotional intelligence and visionary leadership of supply chain managers in the Thai manufacturing industry. SEM was used to test hypotheses. We found that communication $\left(\mathrm{H}_{1}\right)$, creativity $\left(\mathrm{H}_{2}\right)$ and emotional intelligence $\left(\mathrm{H}_{8}\right)$ were the key indicators for the development of visionary leadership. The research findings are supported by the work of (Groves, 2005), which indicated that communication and creative thinking had a positive influence on visionary leadership.

This study found that communication was the key factor, having the highest influence on visionary leadership, followed by creativity and organizational climate, which was consistent with the study of Kakabades et al. (2005). According to Bennis and Nanus (1985), leaders should communicate their visions to subordinators through inspirational communications and written messages, that appeal to shared values. Once leaders share organizational vision and communicate with their subordinators clearly, it enables both the leadership and employees to have a common understanding of corporate purpose and culture. Whenever leaders have positive impact on an organizational vision, employees will have higher trust in the leader and high commitment to the leader, which results in higher levels of performance within the organization (Maladzhi, Yan, \& Makinde, 2012).

This finding was also consistent with Manasse (1986), who stated that creative thinking influences visionary leadership. Creativity is one of the most important qualities of a modern business leader which will foster a successful workplace environment. As a result, the leader must seek solutions to problems, including new administrative approaches to keep up with the environmental change. Therefore, to develop a leader with vision, it is recommended that 
the leader should take an active part in management and leadership skills to improve his or her ability and talent for communication and creative thinking.

This study, however, highlighted that emotional intelligence had a negative impact on visionary leadership $\left(\mathrm{H}_{8}\right)$. This was in contrast with the ideas of Goleman (1995), George (2000), and Kantabutra and Avery (2002), which noted that emotional intelligence influenced visionary leadership and yielded different outcomes. These studies reported that emotional intelligence played an indispensable part in the achievement of a leader in the work place (Goleman, 1995). More specifically, emotional intelligence played an essential role in leadership effectiveness (George, 2000). Leaders who had high emotional intelligence were more effective in influencing and understanding their followers' emotions, thereby gaining their support and responsiveness toward the organization's goals and objectives. Similarly, Olakitan (2014) stated that leaders who adopted emotional intelligence to create well-built relationships also performed well.

On the other hand, our results agreed with Bratton, Dodd, and Brown (2011), who found a negative correlation between emotional intelligence and leader performance $\left(\mathrm{H}_{8}\right)$, for management teams, who exaggerated their abilities. Lubbadeh (2020) stated that leaders might increase their stress level, if they are too involved with the employee's emotions, as they will feel more responsible for such emotions. Concurrently, there are a number of studies, for example, Côté, Decelles, McCarthy, Van Kleef, and Hideg (2011) and Austin, Saklofske, Smith, and Tohver (2014), which debated that people, who have high "Emotional Quotient" or EQ, could use their abilities or even to manipulate others for strategic outcomes, in more malignant and dishonest ways, to meet their interests. Nevertheless, it is believed that the use of emotional intelligence skills in functional purposes relies on the characteristics of the people themselves. It should not be assumed that they have high emotional intelligences (Lubbadeh, 2020). Successful leadership performance relies critically on the ability of a leader to solve complex challenges, which arise in the organization. However, organization is environments that require personal interaction through communication, with the expression of positive emotions (Olakitan, 2014).

Furthermore, we found that emotional intelligence influenced creative thinking $\left(\mathrm{H}_{9}\right)$ and forming the organizational atmosphere. The findings were consistent with Rego, Sousa, Pina e Cunha,Correia and Saur-Amaral (2007) who found that emotionally intelligent leaders operated in ways that inspired creativity among their followers. Likewise, Castro, Gomes, and de Sousa (2012); Côté et al. (2011) indicated a connection between creativity and emotional intelligence.

However, hypothesis, $\mathrm{H}_{4}$, was not supported as it is found to be insignificant, although McLean (2005), and Hunter, Bedell-Avers, and Mumford (2007) reported a positive significant relationship among the variables. The insignificant result in our study might be due to the climate here was a set of attributes, specific to the individual organization and its environment. It depended on the view of members, within the organization and the environment, in which they worked. Gil (2008) studied climate strength - how leaders from consensus and mention that the leadership correlate negatively with climate strength - with a similar conclusion. 
Ironically, the remaining hypotheses showed encouraging results. Organization climate directly affected creativity, $\mathrm{H}_{3}$. The result was aligned with previous work of Ekvall (1996), where organizational climate was considered a significant contributor to enhancing creativity.

The study also highlighted that organization climate directly affected communication, $\mathrm{H}_{5}$. This aligns with Ayundhasurya and Kurniawan (2018), who reported that the climate of organizational had an influence on the satisfaction of non-profit organization communication in Indonesia. A pleasant organizational climate was beneficial for creating more open communication among members. With open communication, members felt more comfortable to be part of an organization. Therefore, it enhanced the communication satisfaction of members, which had a positive impact on job satisfaction.

In addition, we found that emotional intelligence had a positive and major effect on all the components of organizational climate, $\mathrm{H}_{6}$ and communication, $\mathrm{H}_{7}$. It was in line with Momeni (2009) who suggested that emotional intelligence of a leader or manager had an important effect on organizational climate. Moreover, further results also indicated that emotional intelligence significantly positively impacted communication within organizations.

We believe that this research has provided some interesting results in the area of key factors influencing visionary leadership that can assist as a certain inspiration for improving human resource management tools to determine organization success. This research only focused particularly on supply chain managers in Thai manufacturing. Therefore, future studies should emphasize specific attributes of managers or managements, deploying different cultures, and demographic characteristics to formulate a new visionary leadership angle.

\section{References}

Alipour, F. H. (2011). The relationship between organizational climate and communication skills of managers of the Iranian physical education organization. Procedia Social and Behavior Sciences, 30(1), 421-428.

Austin, E. J., Saklofske, D. H., Smith, M., \& Tohver, G. (2014). Associations of the managing the emotions of others (MEOS) scale with personality, the Dark Triad and trait EI. Personality and Individual Differences, 65, 8-13. https://doi.org/10.1016/j.paid.2014.01.060.

Ayundhasurya, R, A., \& Kurniawan, F. (2018). The influence of organization communication climate on organization communication satisfaction to non-profit organization CIOFF Indonesia. Advance in Economics, Business and Management Research, 41(4), 140-144.

Bar-On, R. (1997). BarOn emotional quotient inventory: A measure of emotional intelligence. Toronto, Canada: MultiHealth Systems.

Bass, B. M. (1997). Does the transactional-transformational leadership paradigm transcend organizational and national boundaries? American Psychologist, 52(2), 130-139.

Bass, B. M., \& Riggio, R. E. (2006). Transformational leadership (2nd ed.). Mahwah, NJ: Lawrence Erlbaum Associates, Inc.

Bearden, W. O., Netemeyer, G. R., \& Mobley, M. (1998). Handbook of marketing scales: Multi-Item measure for marketing and customer behavior. Newbury Park, CA: Sage Publication.

Bennis, W., \& Nanus, B. (1985). Leader: The strategies for taking change. New York, NY: Harper and Row.

Berson, Y., Shamir, B., Avolio, B. J., \& Popper, M. (2001). The relationship between vision strength, leadership style, and content. The Leadership Quarterly, 12, 53-73.

Boles, H. W., \& Davenport, J. A. (1975). Introduction to educational leadership. New York: Harper and Row. 
Bowersox, D. J., Closs, D. J., Cooper, M. B., \& Bowersox, J. C. (2013). Supply chain logistics management (4th ed.). New York, NY: McGraw-Hill Higher Education.

Bratton, V. K., Dodd, N. G., \& Brown, F. W. (2011). The impact of emotional intelligence on accuracy of self-awareness and leadership performance. Leadership and Organization Development Journal, 32(2), 127-149.

Brown, K. M., \& Anfara, V. A. (2003). Paving the way for change: Visionary leadership in action at the middle level. NASSP Bulletin, 87(635), 16-34.

Bryman, A. (1992). Charisma and leadership in organizations. Newbury Calif, London: Sage Publications.

Castro, F., Gomes, J., \& de Sousa, F. C. (2012). Do intelligent leaders make a difference? The effect of a leader's emotional intelligence on followers' creativity. Creativity and Innovation Management, 21, 171-182.

Charoenngam, S. N., \& Jablin, F. (1999). An exploratory study of communication competence in Thai organization. Journal of Business Communication, 36(4), 382-418.

Cooper, R. K., \& Sawaf, A. (1997). Executive EQ intelligence in leadership and organization. New York, NY: Grosset \& Putnum.

Côté, S., Decelles, K. A., McCarthy, J. M., Van Kleef. G. A., \& Hideg, I. (2011). The Jekyll and Hyde of emotional intelligence: Emotion-regulation knowledge facilitates both prosocial and interpersonally deviant behavior. Psychological Science, 22(8), 1073-1080. https://doi.org/ 10.1177/0956797611416251.

Creswell, J. W. (2002). Research design: Qualitative, quantitative and mixed methods approaches (2nd ed.). CA: Sage Publications.

Department of Industrial Works, Ministry of Industry. (2019). Business operation. Retrieved from https://www.diw.go.th/hawk/content/php?mode=dataservice \& tabid=1.

Dessler, G. (1998). Leading people and organizations in the $21^{\text {st }}$ century (2nd ed.). Upper Saddle River, NJ: Pearson Prentice Hall.

Dubrin, A. J. (1984). Fundamentals of organizational behaviour (4th ed.). New York, NY: Pergamon Press.

Ekvall, G. (1996). Organizational climate for creativity and innovation. European Journal of Work and Organizational Psychology, 5, 105-123.

Finkelstein, S., \& Hambrick, C. (1997). Strategic leadership: Top executives and their effects on organizations. The Academy of Management Review, 22(3), 802-805.

George, J. M. (2000). Emotions and leadership: The role of emotional intelligence. Human Relations, 53(8), 1027-1055. https://doi.org/10.1177/0018726700538001.

Gil, L. (2008). Climate strength - How leaders from consensus. The Leadership Quarterly, 19, 42-53.

Goleman, D. (1995). Emotional intelligence: Why it can matter more than IQ. New York, NY: Bantam Books.

Goleman, D., Boyatzis, R., \& McKee, A. (2002). Primal leadership. Boston, MA: Harvard Business School Press.

Gravetter, F., \& Wallnau, L. (2014). Essentials of statistics for the behavioral sciences (8th ed.). Belmont, CA: Wadsworth.

Greenberg, J., \& Baron, R.A. (1995). Behaviour in organizations (4th ed.). Needham Heights, MA: Allyn and Bacon.

Grigsby, K. A. (1991). Perception of organization, climate: Influenced by the organization structure. Journal of Nursing Education, 30(2), 81-88.

Groves, K. (2005). Gender difference in social and emotional skill and charismatic leadership. Journal of Leadership and Organizational Studies, 11(3), 30-46.

Guilford, J. P. (1959). Traits of creativity. In H. H. Anderson (Eds.), Creativity and its cultivation (pp. 142-151). New York, NY: Harper \& Row.

Hair, J. F., Black, W. C., Babin, B. J., Anderson, R. E., \& Tatham, R. L. (2006). Multivariate data analysis. Upper Saddle River, NJ: Pearson Prentice Hall.

Hancott, D. E. (2005). The relationship between transformational leadership and organizational performance in the largest public companies in Canada (Unpublished doctoral dissertation). Capella University, Minneapolis, MN.

Hawi, N. S. (2012). Internet addiction among adolescents in Lebanon. Computers in Human Behavior, 28(3), 1044-1053.

Hickman, C. R., \& Silva, M. A. (1984). Creating excellence. New York, NY: New American Library.

Hinterhuber, H. H., \& Friendrich, S. A. (2002). The technology dimension of strategic leadership: the leadership challenge for production economists. International Journal of Production Economics, 77(3), 191-203.

Hinterhuber, H. H., \& Popp, W. (2002). What make a strategist out of a manager? What engineer should know about strategic management? International Journal of Production Economics, 30(31), 297-307. 
Howell, J. M., \& Frost, P. J. (1989). A laboratory study of charismatic leadership. Organizational Behavior and Human Decision Processes, 43(2), 243-269. https://doi.org/10.1016/0749-5978(89)90052-6.

Hoy, W. K., \& Miskel, C. G. (2005). Educational administration: Theory, research, and practice (6th ed.). New York, NY: McGraw-Hill Higher Education.

Hunter, S. T., Bedell-Avers, K. E., \& Mumford, M. D. (2007). The typical leadership study: Assumptions, implications, and potential remedies. The Leadership Quarterly, 18(5), 435-446.

Jacobs, T. O. (1970). Leadership and exchange in formal organizations. Alexandria, VA: Human Resources Research Organization.

Jellen, G., \& Urban. K. (1986). Test for creative thinking drawing production. The Creative Child and Adult Quarterly, 11(8), 107-155.

Kangpen, S. (2008). Administrative factors affecting school effectiveness: Model development and validation (Unpublished doctoral dissertation). Khon Kaen University, Khon Kaen, Thailand.

Kantabutra, S., \& Avery, G. C. (2002). Proposed model for investigating relationships between vision components and business unit performance. Journal of the Australian and New Zealand Academy of Management, 8(2), 22-39.

Kakabades, N., Kakabadse, A., \& Lee-Devis, L. (2005). Visioning the pathway: A leadership process model. European Management Journal, 23(2), 237-246.

Kuei, C. H., Madu, C. N., \& Lin, C. (2001). The relationship between supply chain quality management practices and organizational performance. International Journal of Quality and Reliability Management, 18(8), 864-872.

Kuo, P. (2016). Effects of synchronous web-based instruction on students' thinking styles and creativity. EURASIA Journal of Mathematics, Science and Technology Education, 12(3), 609-619.

Lambert, D. M., Stock, J. R., \& Ellram, L. M. (1998). Fundamentals of logistics management. Boston, MA: McGraw-Hill.

Lubbadeh, T. (2020). Emotion intelligence and leadership-the dark and bright sides. Modern Management Review, 27(1), $39-50$.

Lummus, R. R., \& Vokurka, R. J. (1999). Defining supply chain management: A historical perspective and practical guidelines. Industrial Management and Data Systems, 99(1), 11-17.

Lunenburg, F. C., \& Ornstein, A. C. (1991). Educational administration: Concepts and practices. Belmont, CA: Wardsworth Inc.

Maladzhi, W. R., Yan, B., \& Makinde, O. D. (2012). The impact of innovative leadership on organisational culture within South African small and medium enterprises in the Western Cape, South Africa. African Journal of Business Management, 6(39), 10438-10444, https://doi.org/10.5897/AJBM12.749.

Manasse, A. L. (1986). Vision and leadership: Paying attention to intention. Peabody Journal of Education, 63(1), 150 173.

Manning, T., \& Robertson, B. (2002). The dynamic leader-leadership development beyond the visionary leader. Industrial and Commercial Training, 34(4), 137-143.

Mayer, J. D., \& Salovey, P. (1997). What is emotional intelligence? In P. Salovey \& D. J. Sluyte (Eds). Emotional development and emotional intelligence. New York, NY: Basic Books.

McLean, L. D. (2005). Organizational culture's influence on creativity and innovation: A review of the literature and implications for human resource development. Advances in Developing Human Resources, 7, 226-246. https://doi.org/ $10.1177 / 1523422305274528$.

Meyer, J. P., Paunonen, S. M., Gellatly, I. R., Goffin, R. D., \& Jackson, D. N. (1989). Organizational commitment and job performance: It's the nature of commitment that counts. Journal of Applied Psychology, 74(1), 152-156.

Momeni, N. (2009). The relation between managers' emotional intelligence and the organizational climate they create. Public Personnel Management, 38(2), 35-48.

Nanus, B. (1992). Visionary leadership: Creating a compelling sense of direction for your organization. San Francisco, CA: Jossey-Bass Publishers.

Olakitan, O. O. (2014). Emotional intelligence and perceived leadership behaviour effectiveness in organizations. International Journal of Humanities and Social Science, 4(2), 262-269.

Owens, R. G. (1995). Organization behavior in education (5th ed.). Boston, MA: Allyn and Bacon Press.

Podsakoff, P. M., MacKenzie, S. B., Moorman, H., \& Fetter, R. (1990). Transformational leader behaviors and their effects on followers. The Leadership Quarterly, 1(2), 107-142.

Ravinelli, R. J., \& Hambleton, R. K. (1997). On the use content specialists in the assessment of criteria reference test Item validity. Journal of Education Research, 2, 49-60. 
Rego, A., Sousa, F., Pina e Cunha, M., Correia, A., \& SaurAmaral, I. (2007). Leader self-reported emotional intelligence and perceived employee creativity: An exploratory study. Creativity and Innovation Management, 16(3), $250-264$. https://doi.org/10.1111/j.1467-8691.2007.00435.x.

Robbins, S. P. (2003). Organisational behaviour (10th ed.). Englewood Cliffs, NJ: Prentice Hall, Inc.

Sashkin, M. (1987). A new vision of leadership. Journal of Management Development, 6(4), 19-28.

Steer, R. M., \& Porter, L. W. (1991). Motivation and work behavior (5th ed.). New York, NY: McGraw-Hill.

Torance, E. P. (1962). Education and creative potential. Minneapolis, MN: University of Minnesota Press.

Van Hock, R. I., Chatham, R., \& Wilding, R. (2002). Manager in supply chain management, the critical dimension. Supply Chain Management: An International Journal, 7(3), 119-125.

Van Staden, J. F., Scheepers, J. M., \& Rieger, H. S. (2000). Lokus van beheer en transformasionele leierskap [Behavior focus on transformational leaps]. Journal of Industrial Psychology, 26(3), 8-14.

Vlok, A. (2012). A leadership competency profile for innovation leaders in a science-based research and innovation organization in South Africa. Procedia - Social and Behavioral Sciences, 41, 209-226.

Wallach, M., \& Kogan, N. (1965). Model of thinking in young children: A study of creativity-intelligence distinction. New York, NY: Holt Rinchart and Winston.

Wannasri, J. (2007). The cause relationship of factors affective visionary leadership of management in the high school in Bangkok (Unpublished doctoral dissertation). Naresuan University, Phitsanulok, Thailand.

Weisinger, H. (1998). Intelligence. Cambridge, England: Cambridge University Press.

Westley, F., \& Mintzberg, H. (1989). Visionary leadership and strategic management. Strategic Management Journal, 10, $17-32$.

White, D., \& Bedner, D. (1999). Organizational behavior: Understanding and managing people at work. Toronto, Canada: Allyn and Bacon.

Williams, R. B. G., Mathews, A., \& MacLeod, C. (1994). The emotional stoop task and psychopathology. Psychological Bulletin, 120, 3-24.

Zaccaro, S. J., \& Banks, D. (2004). Leader visioning and adaptability: Bridging the gap between research and practice on developing the ability to manage change. Human Resource Management, 43(4), 367-380. 